\title{
KNOWLEDGE AND ATTITUDE OF MEDICATION ERROR AMONG NURSES IN FEDERAL NEURO- PSYCHIATRIC HOSPITAL, CALABAR
}

\author{
Dr. Umoh, Edet Okon and Opue, Blessing Oduenyi \\ DOI: 10.47760/cognizance.2021.v01i06.003
}

\begin{abstract}
This study was conducted to assess knowledge and attitude of medication among Nurses in Federal Neuropsychiatric Hospital, Calabar. Three (3) research questions were raised and one hypothesis formulated to direct the study. The descriptive cross-sectional survey design was used to study a total of one hundred and two (102) nurses selected from the study area using the stratified random sampling technique. A well developed and structured questionnaire was used for data collection. The questionnaire was duly validated and its reliability ensured. Data collected were analyzed using descriptive statistics of frequency count, simple percentage, mean, weighted mean, and standard deviation. The study hypothesis was tested using Pearson Product Moment Correlation Coefficient analysis with its significance level set at 0.05 . Findings of the study revealed that majority (73.6\%) of the nurses used for the study had adequate knowledge of medication error, and majority (72.6\%) had positive attitude towards prevention of medication error in the Hospital. Factors that affect safe medication practices among the nurses include: individual negligence, excessive workload, inadequate staff strength, poor working environment, lack of staff development and training, lack of equipment and supplies, non-regular review of patient's drugs by doctors, and prescription of under dosage drug by doctors. There is a statistically significant and positive relationship between knowledge and attitude of nurses towards prevention of medication error. Based on these findings, it was recommended that government should employ more qualified nurses to increase the strength of nurses in the Hospital and improve the nurse-patient ratio to avoid excessive workload which is a strong and significant contributing factor to medication error among nurses in the Hospital.
\end{abstract}

Keywords: Medication errors, Knowledge, Attitude and Factors

\section{Introduction}

Medication errors have been broadly defined as "any error in prescribing, dispensing, or administration of drugs, irrespective of whether such errors lead to adverse consequences or not" (William, 2017). They are essentially 'failures of the treatment process that lead to, or has the potential to lead to, harm to the patients' (Ferner \& Aronson, 2016). They are regarded as the most preventable causes of patient harm with significant contributions to adverse drug events occurrences in hospitalized patients and are often the major reason for hospital readmissions. Such adverse drug events due to preventable medication errors lead to prolonged hospital stay, significant increase in cost of care and occasionally to death (Hug, Keohane, Seger, Yoon \& Bates, 2012).

The incidence of medication error varies widely worldwide between 2 and $14 \%$ as a result of the different definitions and methodologies employed to study these errors (Wilmer, Louie, Dodek \& Wong, 2019). Prescription and drug administration processes are found to be associated with the largest numbers of medication errors recorded irrespective of whether these results in harms or 
not (Buckley, Erstad, Kopp, Theodorou \& Priestley, 2017). A study by Bohand et al.(2019) assessing specifically the rate of dispensing errors by a unit drug dispensing system within the central pharmacy and cardiovascular department of a 354 bed military hospital in France found a medication error rate of $2.5 \%$. The most frequent types of dispensing errors found were improper dose $(31.8 \%)$ and omission (30.2\%). Out of all the errors detected, $29.2 \%$ and $16.6 \%$ had the potential to cause significant and serious adverse drug events respectively.

The United States Food and Drug Administration (FDA) believes that lack of knowledge is one of the human factors most frequently associated with error (Hsaio et al, 2017). Indeed, several studies that have evaluated the pharmacological knowledge of nurses and their calculation skills detect inadequate nursing knowledge (Fleming, Brady \& Malone, 2018). The percentage of errors related to knowledge deficits is however not clear. Some studies such as those conducted by Latif, Rawat, Pustavoitau, Pronovost and Pham, in 2015 and Kendall-Gallagher and Blegen in 2017 showed that about half of the therapeutic errors in Intensive Care Unit (ICU) are the result of knowledge and/or performance deficits.

Apart from lack of knowledge, negligence nursing care is found to be related to error (Shahrokhi, Ebrahimpour \& Ghodousi, 2018). Medical science, as well as nursing care, cannot be considered as a profession that only requires technical and cognitive skills. It should be considered as the integration of this concrete ability with an "innate attitude of caring" (Gastmans, 2019). The care provided by nurses with a good attitude is more frequently related to safe practice. Gastmans (2019) believes that nurses with this attitude are constantly looking for the best nursing practice. Another study conducted by Lawton et al (2016) showed that nurses that consider their role as "just a job" had a greater propensity to error. The occurrence of medication errors committed by a nurse is inversely related to job satisfaction and commitment of the nurse ( $\mathrm{Lu}$, Chang \& Wu, 2017). Similarly, several other studies showed behaviours that are directly related to a medication error, such as failure to comply with guidelines, protocols or procedures, or the ineffective controls or absence of double controls (Blignaut, Coetzee, Klopper \& Elis, 2017). The literature showed most frequent medication errors involving missing or bypassing the administration, wrong-medication, wrong dose, wrong patient, wrong route, wrong rate, wrong timing.

Other factors that contribute to the occurrence of harmful or potentially harmful events have been divided into: (i) factors related to the personal and professional characteristics that are human factors, of the healthcare workers and (ii) factors related to the organization of the drug management process (Donati, Tartaglini \& Muzio, 2015). The latter organizational factors includes workplace conditions, risk management strategies, learning process, workload, overcrowding, lack of staff and shift works (Di et al, 2019). Human factors include personal and professional characteristic of registered nurses. Drug administration and management are integral part of the nurse's role: nurses spend up to $40 \%$ of their time administrating drugs (Armitage \& Knapman, 2018). So, medication errors are a persistent problem associated with nursing practice. It is upon the above backdrop that this study investigates the knowledge and attitude of medication error among nurses in Federal Neuropsychiatric Hospital, Calabar, Cross River State. 


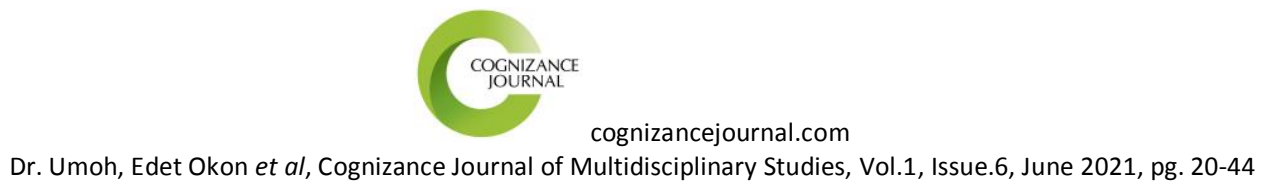

ISSN: 0976-7797

\section{Statement of problem}

Issues of medication error are very rampant posing problem to the patients with disregard to the profession. Circumstantial evidence suggests that medical mistakes are very common in low and middle income countries like Nigeria. These mistakes often result in death, disability or financial losses, yet errors are rarely reported and audited. Recognizing medical errors is particularly difficult due to various reasons, including information barriers between clients and providers, and in some cases deliberate effort to cover up.

In Calabar Psychiatric Hospital, medication error is not strange. Monthly Nursing Audit Report reveals series of medication error like using a wrong for a patient, charting a wrong drug for one served, charting a drug not swallowed by a patient, administering drug through a wrong route, and others. This prevails over the last quarter of 2020 i.e. October, November and December in all acute wards of the hospital. Effect of this result in prolong psychosis and non-improvement in mental state, aggression, drug reaction, fight, insubordination, attempted escape and relapse (FNPH/NAR/vol.1). Worst hit was October 2020 following ENDSARS protest when vandals destroyed the facility and cart away equipments and drugs. Documentation was difficult and patients roam without control following the incident. Nurses says most error arise as a result of poor light and light outage at night.

Though the Hospital Management through the current digital Medical Director and Nursing Department has set in place Quality Improvement Team, Doctor on Call, Standard and Procedure Committee, Nursing Coordinators and Nursing Supervisors, they could not limit nor prevent occurrence of medication error among nurses. This is sequel to the fact that most error occurs at evening and night shift where few nurses are placed on duty. And, above teams and committees only operate on motivation.

However, there is a paucity of literature on this subject matter in Cross River State as a whole and in Federal Neuropsychiatric Hospital in particular. This study is therefore conducted to fill this gap. Hence, it is pertinent to ask; what is the knowledge and attitude of medication error among psychiatric nurses in Federal Neuropsychiatric Hospital, Calabar, Cross River State?

\section{Purpose of study}

The general purpose of this study was to assess knowledge and attitude of medication error among nurses in Federal Neuropsychiatric Hospital, Calabar, Cross River State.

Specifically, the study sought to:

i. Determine the level of knowledge of medication error among nurses in Federal Neuropsychiatric Hospital, Calabar.

ii. Examine the attitude of nurses towards medication error in Federal Neuropsychiatric Hospital, Calabar.

iii. Find out the factors affecting safe medication practices among nurses in Federal Neuropsychiatric Hospital, Calabar.

\section{Research questions}

i. What is the level of knowledge of medication error among nurses in Federal Neuropsychiatric Hospital, Calabar? 


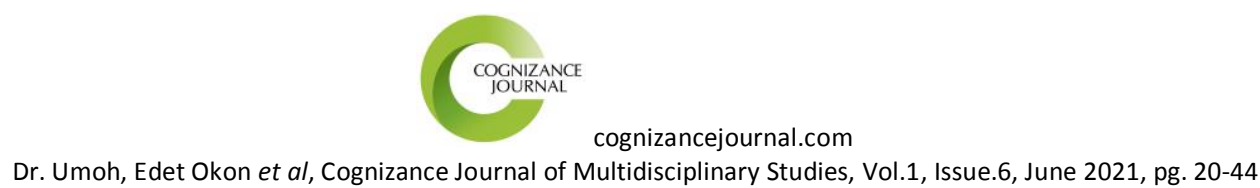

ISSN: 0976-7797

ii. What is the attitude of nurses towards medication error in Federal Neuro-psychiatric Hospital, Calabar?

iii. What are factors affecting safe medication practices among nurses in Federal Neuropsychiatric Hospital, Calabar?

\section{Hypothesis}

$\mathrm{H}_{0}$ : There is no significant relationship between knowledge and attitude of medication errors among nurses in Federal Neuropsychiatric Hospital, Calabar

\section{Significance of study}

The study findings will be useful to both public and private healthcare providers especially those in a psychiatric setting in helping them make informed decisions with regard to medication error. The study will make significant contributions to theory and practice with regards to medication error and bridge the gap between theory and practice.

The study is therefore expected to inform decision makers on the strategies to guide the development of an effective quality health care industry. It will form a basis through which both public and private healthcare providers will improve and lower their medication error and techniques. The study will also give additional information to the already existing body of literature regarding medical and medication errors. It will serve as a reference material to students and researchers respectively.

\section{Limitations of the study}

The following limitations were met by the researcher in the course of survey:

$>$ Ill health of one of the family members

$>$ Non documentation of events by nursing officers on duty

$>$ Poor storage of ward information resulting to information loss

\section{METHODOLOGY}

\section{Research design}

This study adopts a cross-sectional descriptive survey design. The survey design particularly aimed at describing the nature of a situation that exists at the time of the study. It gives a precise representation of the characteristic of persons, phenomena, situation, population or groups and/or the rate with which certain occurrence takes place. Ndiyo (2010) describes the survey design as a study design that involves selecting and studying of samples derived from populations of interest to ascertain the relative occurrence, distribution and interrelations of variables of sociological and psychological relevance. He stressed that survey design typically made use of questionnaires and interviews to elicit opinions, attitude, preferences, and perceptions of individuals of specific interest to the researcher. With these assertions, it is obvious that survey design is aimed at eliciting information on specific facts regarding the entire population of a study from a representative sample of this population, and through a questionnaire and/or interview.

\section{Population of study}

The population of this study consists of mental health nurses in any of 10 wards and/units in Federal Neuropsychiatric Hospital, Calabar, Cross River State. Based on a recent Administrative 


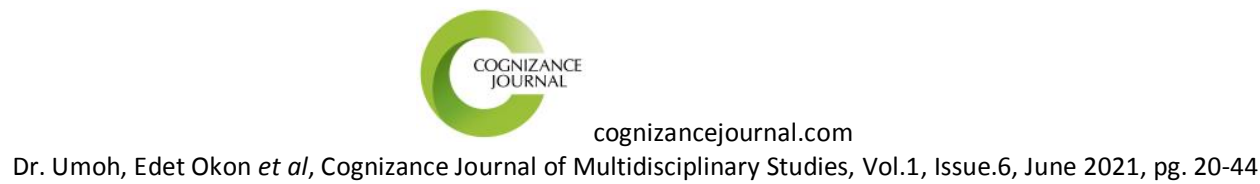

ISSN: 0976-7797

Report of the Hospital, the population of nurses in the Hospital stands at 111 which constitute the target population of the present study.

\section{Sample and sampling technique}

The sample size of this study is made up of 102 clinical psychiatric nurses in Federal Neuropsychiatric Hospital, Calabar. This sample size was obtained using Taro Yemen formula for sample size determination. This formula is used when the target population of the study is known such as in the case of this study. The formula is as stated below:

$$
\begin{aligned}
& \mathrm{n}=\frac{\mathrm{N}}{1+\mathrm{N}(\mathrm{e})^{2}} \\
& \text { Where } \quad \mathrm{n}=\text { sample size } \\
& \mathrm{N}=\text { population size }=111 \\
& \mathrm{e}=\text { level of precision }=\quad 0.05 \\
& \mathrm{n}=\frac{111}{1+111(0.05)^{2}} \\
& =\quad 86.9=87 \text { approx. }
\end{aligned}
$$

Factoring the non-response rate of $15 \%$ : the sample size was increased by $15 \%$

Which is $\underline{15}=0.15$

100

Applying the formula

$$
1-\frac{\mathrm{N}}{\text { Non-response rate }}
$$

When I substituted these figure in the formula I had;

$1-0.15=0.85$

$=\underline{87}$

$$
\overline{0.85}
$$

$=102.4=102$ approx.

Hence, the sample size for this study was approximately 102.

The sampling technique adopted for the study was the stratified random sampling. Each Ward/unit within the Hospital where nurses render their services was referred to as a stratum of the study population. The hospital consists of a total of $10 \mathrm{Wards} / \mathrm{Units}$. To select nurses from each ward or unit a proportionate sampling technique was used. The sampling distribution for this study is presented in Table 1 below.

\section{Table 1: Sampling distribution}

\begin{tabular}{cccc}
\hline S/No. & Wards/Unit & Nurse population & Sample size \\
\hline 1. & Ward 1 & 15 & 13 \\
2. & Ward 2 & 14 & 13 \\
3. & Ward 3 & 14 & 13 \\
4. & Ward 4 & 14 & 13 \\
5. & Ward 5 & 13 & 12 \\
6. & Ward 6 & 10 & 9 \\
7. & Ward 7 & 12 & 11
\end{tabular}


cognizancejournal.com

Dr. Umoh, Edet Okon et al, Cognizance Journal of Multidisciplinary Studies, Vol.1, Issue.6, June 2021, pg. 20-44

ISSN: 0976-7797

$\begin{array}{cccc}8 . & \text { OPE } & 13 & 12 \\ 9 . & \text { OPC } & 3 & 3 \\ 10 . & \text { Staff Clinic } & 3 & 3 \\ & \text { Total } & \mathbf{1 1 1} & \mathbf{1 0 2}\end{array}$

To select the nurses from the respective Wards/Units, a random sampling technique was used.

Instrument for data collection

The instrument for data collection was a structured questionnaire constructed in line with the study's objectives. The questionnaire was divided into four (4) sections A-D. Section A seeks to ascertain personal data of respondents. Section B consists of items that sought to elicit the respondents' knowledge of medication error, while sections C-D had items structured on a 4 point Likert scale ranging from strongly Agree (SA), Agree (A), Disagree (D), and strongly Disagree (SD). Section C was on the respondents' attitude towards medication error, and section D elicits the factors that affects safe medication practices among the nurses. Items measuring the respondents' attitude were scored based on the Likert scale (4 through 1 and vice versa for positive and negative questions) and categorized into positive and negative attitude respectively.

\section{Validity of instrument}

Validity of a research instrument refers to the extent to which the instrument measures what it is designed to measure. In this study, face validity was established. Hence, the questionnaire was presented to the supervisor and an expert in Test and Measurement to evaluate the relevance of the content and clarity of the statements. The necessary suggestions from the validators were effected by the researcher before using the instrument for data collection.

\section{Reliability of instrument}

To determine the reliability of the research instrument, test-retest method was used. The questionnaire was administered to nine (9) mental health nurses in the Hospital who were not included in the main study. This same process was repeated after two weeks interval as same questionnaire were administered to the same respondents in the first test. Data collected in the first and second tests were coded, scored and analyzed using Pearson Correlation Coefficient. A reliability coefficient of the range 0.892 to 0.925 (see Table 2 below) was obtained showing that the instrument is reliable and could adequately measure the variables under study.

Table 2: Estimation of Reliability Coefficient through test-retest technique

\begin{tabular}{|c|l|c|c|c|c|c|}
\hline S/No & \multicolumn{1}{|c|}{ Variables } & $\mathbf{N}$ & $\begin{array}{c}\text { Test } \\
\text { positions }\end{array}$ & $\overline{\mathbf{X}}$ & $\mathbf{S D}$ & $\mathbf{r}_{\text {-cal }}$ \\
\hline 1. & Knowledge of medication error & 9 & $1^{\text {st }}$ test & 4.27 & 0.83 & 0.892 \\
& & & $2^{\text {nd }}$ test & 4.43 & 0.73 & \\
\hline 2. & Attitude towards medication error & 9 & $1^{\text {st }}$ test & 17.20 & 0.48 & 0.901 \\
& & & $2^{\text {nd }}$ test & 17.10 & 0.64 & \\
\hline 3. & Factors affecting safe medication & 9 & $1^{\text {st }}$ test & 22.60 & 0.67 & 0.925 \\
& practices & & $2^{\text {nd }}$ test & 22.63 & 0.56 & \\
\hline
\end{tabular}

Source: Questionnaire 


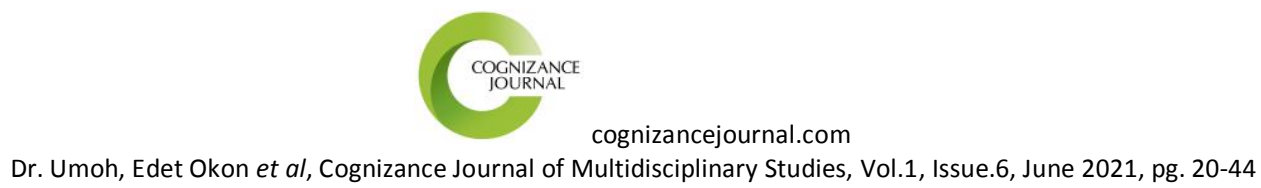

ISSN: 0976-7797

\section{Procedure for data collection}

The researcher adopted a face-to-face administration of the questionnaire. With the aid of a student nurse, the researcher distributed the questionnaire to clinical nurses in various wards/clinics in the hospital. The purpose of the study was clearly stated to the respondents and confidentiality of information assured. However, repeated visits were made to cover those respondents in morning, evening and night shifts; and on-the-spot collection of responded questionnaire was maintained.

\section{Method of data analysis}

Item by item descriptive analyses of the data was carried out to show response frequency and percentage including mean and standard deviation using SPSS version 20. The hypothesis was tested using Pearson product moment correlation analysis at $95 \%$ confidence interval.

\section{Ethical consideration}

For the success of this research work, some ethical issues were considered. A letter of introduction was obtained from the Head of Department of Nursing Science, National Open, Calabar study centre and submitted to the Chief Medical Director of Federal Neuropsychiatric Hospital, through the Director Nursing Services to obtain permission for the study. Confidentiality was assured to the study's participants and same was maintained as names were not required. The participants were assured of respect of their freedom of choice and that they will not be prejudiced in any way if they choose not to participate in the study. Also, the Authors of books and journals used for the study were properly referenced according to the recommended standard for this research work.

\section{RESULTS OF FINDING AND ANALYSIS}

Presentation and analysis of demographic data

Table 3: Percentage distribution of respondents by gender $(\mathrm{n}=102)$

\begin{tabular}{cllcc}
\hline S/No & \multicolumn{1}{c}{ Gender } & Frequency & Percentage $(\%)$ \\
\hline 1. & Male & 43 & 42.2 \\
2. & Female & 59 & 57.8 \\
& & Total & $\mathbf{1 0 2}$ & $\mathbf{1 0 0}$ \\
& & & & \\
\hline
\end{tabular}

Source: Questionnaire

The Table above reveals that $43(42.2 \%)$ out of the 102 nurses used for this study were male while $59(57.8 \%)$ were female. 


\section{GENDER}

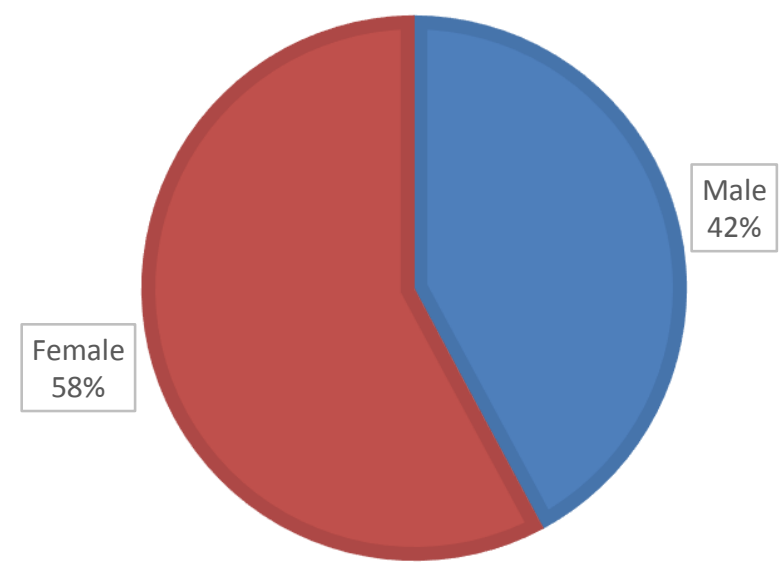

Figure 2: Bar chart showing the respondents by gender

Table 4: Percentage distribution of respondents by age $(n=102)$

\begin{tabular}{cccc}
\hline S/No & \multicolumn{1}{c}{ Age (years) } & Frequency & Percentage (\%) \\
\hline 1. & $\leq 20$ & 4 & 3.9 \\
2. & $21-30$ & 16 & 15.7 \\
3. & $31-40$ & 36 & 35.3 \\
4. & $41-50$ & 29 & 28.4 \\
5. & Above 50 & 17 & 16.7 \\
& Total & $\mathbf{1 0 2}$ & $\mathbf{1 0 0}$ \\
\hline
\end{tabular}

Source: Questionnaire

Table 4 shows that 4 (3.9\%) out of the 102 nurses were less but not more than 20 years of age, $16(15.7 \%)$ were between 21 - 30 years, while $36(35.3 \%)$ were between $31-40$ years, 29 (28.4\%) were between 41 - 50 years, and 17 (16.7\%) were more than 50 years of age. 
cognizancejournal.com

Dr. Umoh, Edet Okon et al, Cognizance Journal of Multidisciplinary Studies, Vol.1, Issue.6, June 2021, pg. 20-44

ISSN: 0976-7797

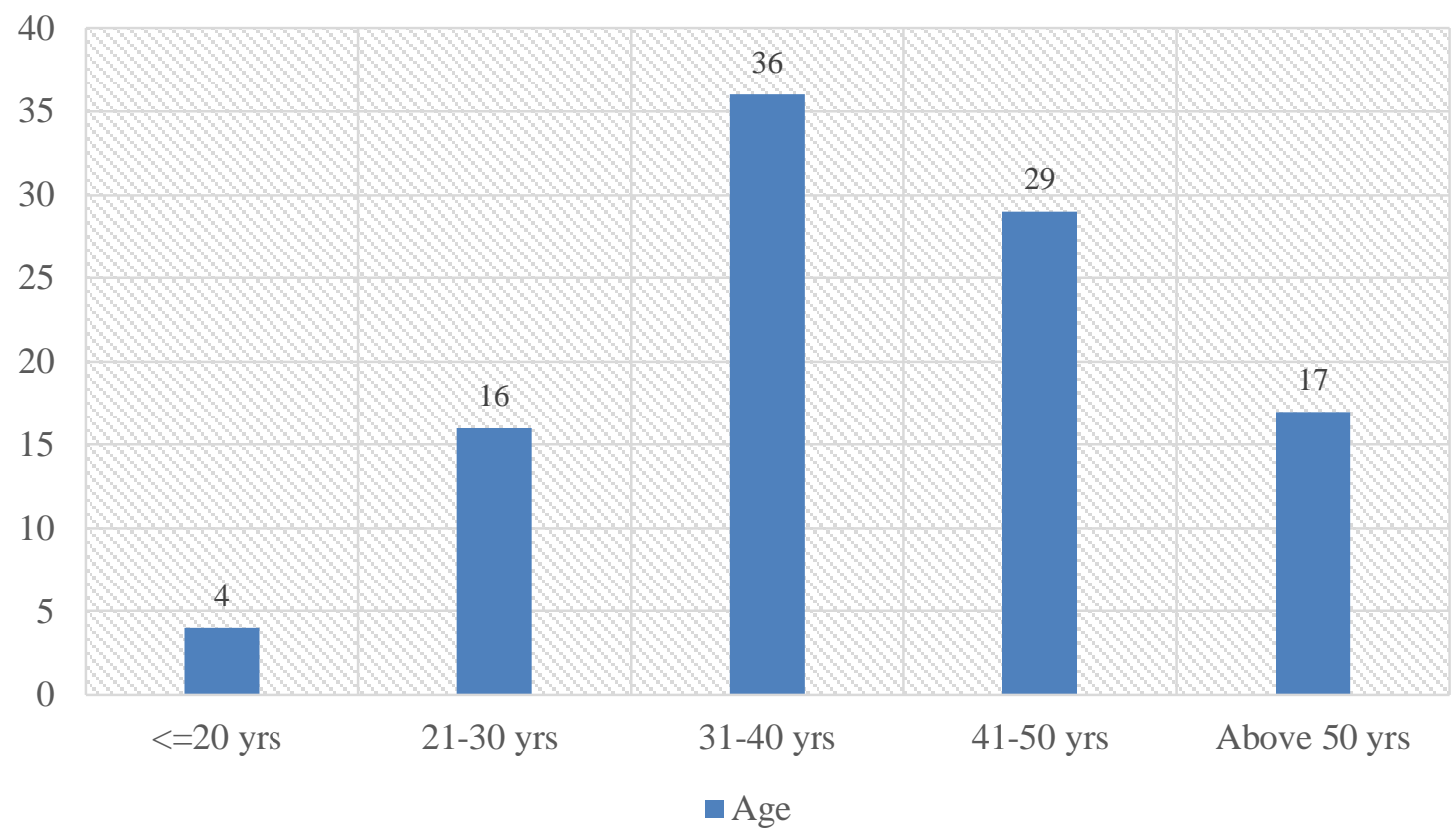

Figure 3: Bar chart showing the respondents by age

Table 5: Percentage distribution of respondents by marital status $(\mathrm{n}=102)$

\begin{tabular}{clcc}
\hline S/No & Marital status & Frequency & Percentage (\%) \\
\hline 1. & Single & 28 & 27.5 \\
2. & Married & 45 & 44.1 \\
3. & Separated & 7 & 6.9 \\
4. & Divorced & 9 & 8.8 \\
5. & Widow & 13 & 12.7 \\
& & $\mathbf{1 0 2}$ & $\mathbf{1 0 0}$ \\
& & & \\
\hline
\end{tabular}

Source: Questionnaire

Table 4 above presents the respondents by marital status. The Table shows that 28 (27.5\%) out of the 102 respondents were single, $45(44.1 \%)$ were married, while 7 (6.9\%) were separated, 9 $(8.8 \%)$ were divorced, and $13(12.7 \%)$ were widow and/or widower. 
cognizancejournal.com

Dr. Umoh, Edet Okon et al, Cognizance Journal of Multidisciplinary Studies, Vol.1, Issue.6, June 2021, pg. 20-44

ISSN: 0976-7797

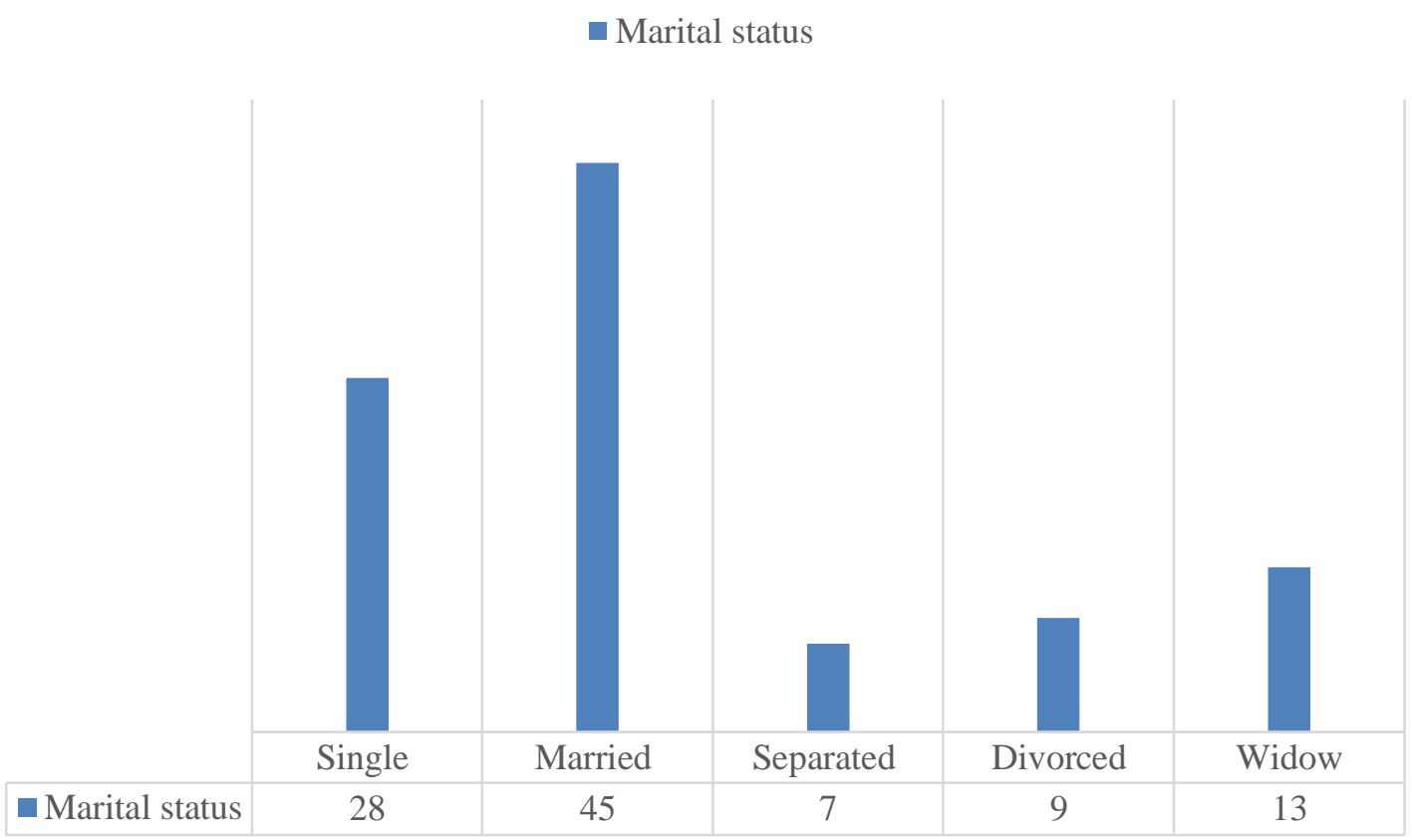

Figure 4: Bar chart showing the respondents by marital status

Table 6: Percentage distribution of respondents by religion $(\mathrm{n}=102)$

\begin{tabular}{clcc}
\hline S/No & \multicolumn{1}{c}{ Religion } & Frequency & Percentage (\%) \\
\hline 1. & Muslim & 4 & 3.9 \\
2. & Christianity & 98 & 96.1 \\
3. & Traditional & - & 0.0 \\
& Total & $\mathbf{1 0 2}$ & $\mathbf{1 0 0}$ \\
\hline
\end{tabular}

Source: Questionnaire

The above Table reveals that among the 102 respondents used for this study, 4 (3.9\%) were Muslims, while 98 (96.1\%) were Christians, and none of them was a traditional worshipper. 


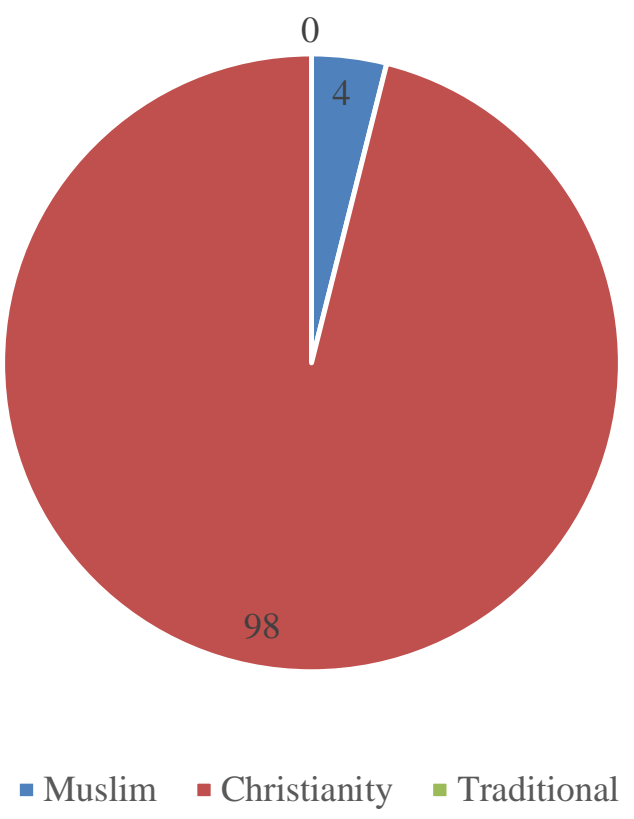

Figure 5: Bar chart showing the respondents by religion

Table 7: Percentage distribution of respondents by Rank $(n=102)$

\begin{tabular}{|c|c|c|c|}
\hline S/No & Rank & Frequency & Percentage $(\%)$ \\
\hline 1. & NO II & 26 & 25.5 \\
\hline 2. & NO I & 21 & 20.6 \\
\hline 3. & SNO & 18 & 17.6 \\
\hline 4. & PNO & 17 & 16.7 \\
\hline 5. & ACNO & 11 & 10.8 \\
\hline \multirow[t]{2}{*}{6.} & $\mathrm{CNO}$ & 9 & 8.8 \\
\hline & Total & 102 & 100 \\
\hline
\end{tabular}

\section{Source: Questionnaire}

Table 7 above shows that $26(25.5 \%)$ out of the 102 nurses used for the study were nursing officer II, 21 (20.6\%) were nursing officer I, while 18 (17.6\%) were senior nursing officer, 17 (16.7\%) were principal nursing officer, 11 (10.8\%) were acting chief nursing officer, and 9 $(8.8 \%)$ were chief nursing officer. 
cognizancejournal.com

Dr. Umoh, Edet Okon et al, Cognizance Journal of Multidisciplinary Studies, Vol.1, Issue.6, June 2021, pg. 20-44

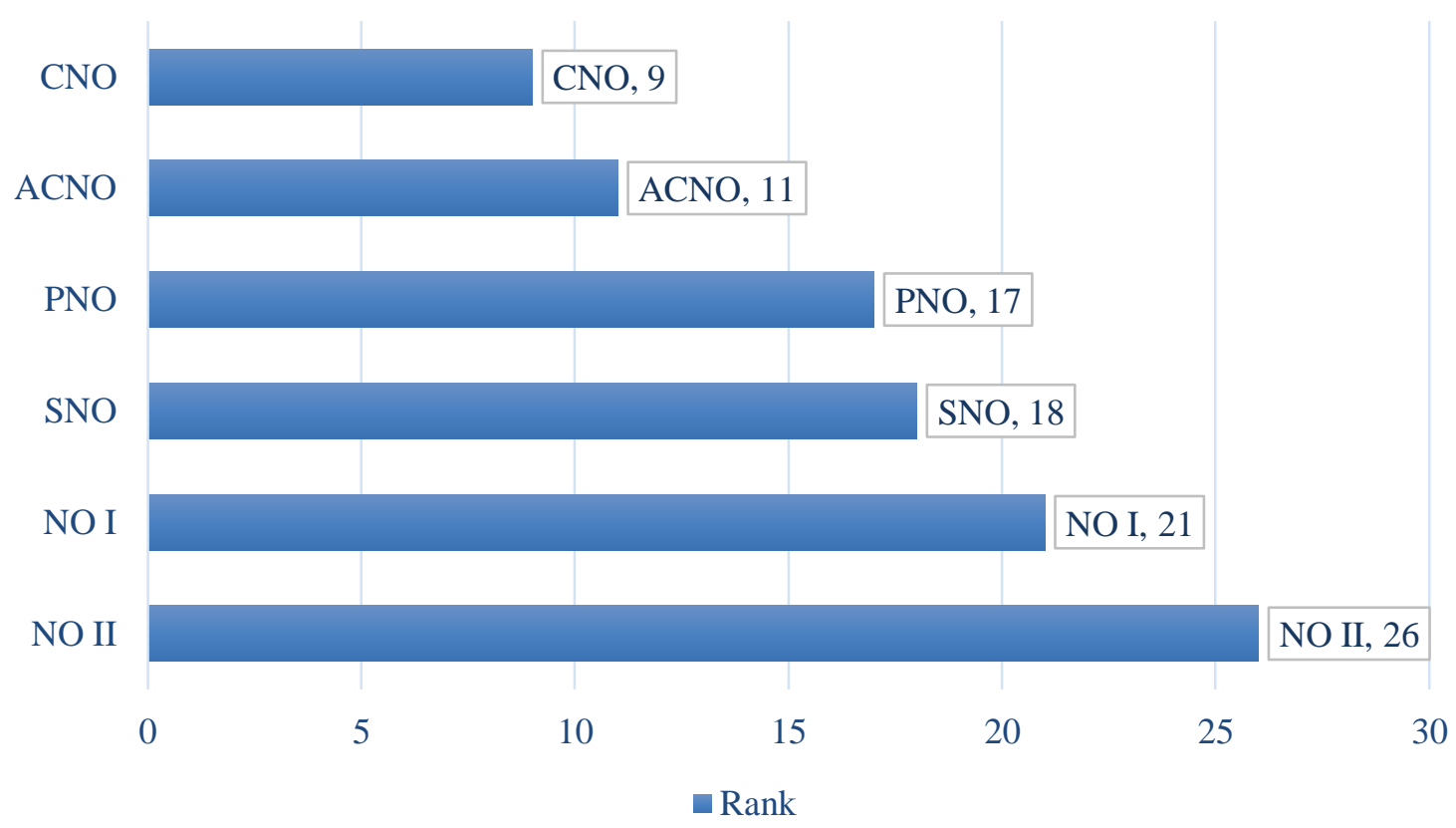

Figure 6: Bar chart showing the respondents by rank

Table 8: Percentage distribution of respondents by years in service $(\mathrm{n}=102)$

\begin{tabular}{clcc}
\hline S/No & Years in service & Frequency & Percentage (\%) \\
\hline 1. & $\leq 10$ years & 37 & 36.3 \\
2. & $11-20$ years & 32 & 31.3 \\
3. & $21-30$ years & 19 & 18.6 \\
4. & Above 30 years & 14 & 13.7 \\
& Total & $\mathbf{1 0 2}$ & $\mathbf{1 0 0}$ \\
& & &
\end{tabular}

Source: Questionnaire

Table 8 above shows that 37 (36.3\%) of the 102 respondents had worked in the hospital for less but not more than 10 years prior to the study, while 32 (31.3\%) had worked for 11-20 years, 19 (18.6\%) had worked for 21 - 30 years, and 14 (13.7\%) had worked in the Hospital for more than 30 years as at the time of this study. 
cognizancejournal.com

Dr. Umoh, Edet Okon et al, Cognizance Journal of Multidisciplinary Studies, Vol.1, Issue.6, June 2021, pg. 20-44

\section{口Years in service}
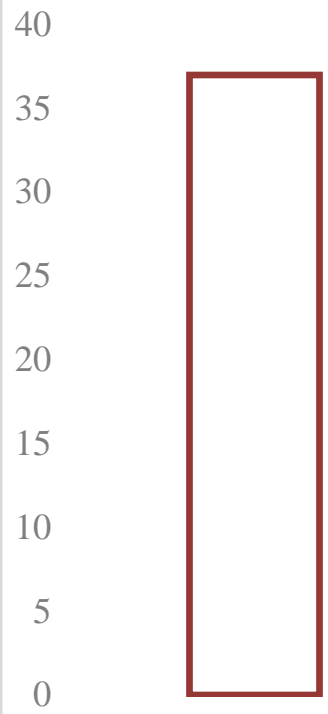

$<=10$ yrs
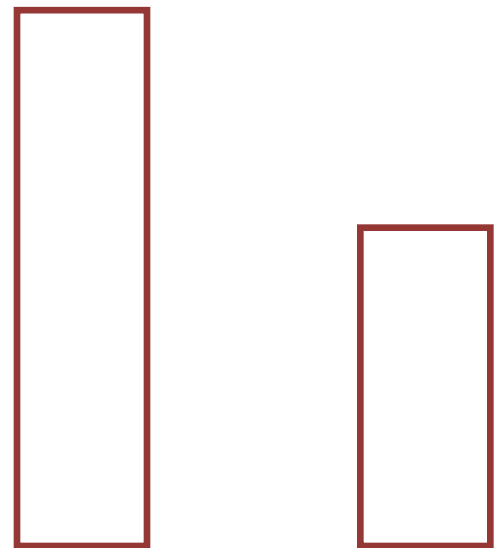

$11-20$ yrs

$21-30$ yrs

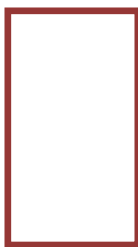

$>30$ yrs

Figure 7: Bar chart showing the respondents by years in service

\section{Answering of research questions}

Research question 1: What is the level of knowledge of medication error among nurses in Federal Neuropsychiatric Hospital, Calabar?

To answer this question, items 7-11 of the research questionnaire were sorted and analyzed, and results presented in Table 9 below.

Table 9: Knowledge of medication error among the respondents $(\mathrm{n}=102)$

\begin{tabular}{|c|c|c|c|c|c|c|c|c|c|}
\hline \multirow[t]{2}{*}{ S/No. } & \multirow[t]{2}{*}{ Items } & \multicolumn{2}{|c|}{ Yes } & \multicolumn{2}{|c|}{ No } & \multicolumn{2}{|c|}{ I don't know } & \multicolumn{2}{|c|}{ Total } \\
\hline & & $\mathrm{n}$ & $\%$ & $\mathrm{n}$ & $\%$ & $\mathrm{n}$ & $\%$ & $\mathrm{n}$ & $\%$ \\
\hline 7. & $\begin{array}{l}\text { Medication error means giving } \\
\text { wrong medication to the } \\
\text { patient, which include wrong } \\
\text { dose, wrong route, and wrong } \\
\text { documentation. }\end{array}$ & 97 & 95.1 & - & - & 5 & 4.9 & 102 & 100 \\
\hline 8. & $\begin{array}{l}\text { Medication error could cause } \\
\text { permanent disability or death } \\
\text { in patient }\end{array}$ & 89 & 87.3 & 2 & 1.9 & 11 & 10.8 & 102 & 100 \\
\hline 9. & $\begin{array}{l}\text { Medication error could result } \\
\text { during: } \\
\text { a. Drug prescription } \\
\text { b. Drug dispensing } \\
\text { c. Drug administration } \\
\text { d. None of the above }\end{array}$ & $\begin{array}{l}66 \\
81 \\
94 \\
8\end{array}$ & $\begin{array}{c}64.7 \\
79.4 \\
92.2 \\
7.8\end{array}$ & $\begin{array}{c}26 \\
16 \\
8 \\
94\end{array}$ & $\begin{array}{c}25.5 \\
15.7 \\
7.8 \\
92.2\end{array}$ & $\begin{array}{l}10 \\
5 \\
- \\
-\end{array}$ & $\begin{array}{c}9.8 \\
4.9 \\
- \\
-\end{array}$ & $\begin{array}{l}102 \\
102 \\
102 \\
102\end{array}$ & $\begin{array}{l}100 \\
100 \\
100 \\
100\end{array}$ \\
\hline
\end{tabular}


cognizancejournal.com

Dr. Umoh, Edet Okon et al, Cognizance Journal of Multidisciplinary Studies, Vol.1, Issue.6, June 2021, pg. 20-44

ISSN: 0976-7797

\begin{tabular}{|l|l|c|c|c|c|c|c|c|c|}
\hline 10. & $\begin{array}{l}\text { Medication error should not be } \\
\text { reported to the patient and } \\
\text { patient's family }\end{array}$ & 78 & 76.5 & 9 & 8.8 & 15 & 14.7 & 102 & 100 \\
\hline 11. & $\begin{array}{l}\text { Noise making could lead to } \\
\text { medication error. }\end{array}$ & 71 & 69.6 & 25 & 24.5 & 6 & 5.9 & 102 & 100 \\
\hline
\end{tabular}

Source: Questionnaire

The respondents' knowledge of medication error is presented in Table 9 above. The Table shows that out of the 102 respondents used for the study, 97 (95.1\%) answered 'yes' that medication error means giving wrong medication to the patient, which include wrong dose, wrong route, and wrong documentation, none of the respondents responded 'no' to this item of the questionnaire, while $5(4.9 \%)$ said they don't know. $89(87.3 \%)$ respondents answered in the affirmative that 'medication error could cause permanent disability or death to the patient', while $2(1.9 \%)$ said 'no', and $11(10.8 \%)$ said they don't know. When the respondents were asked when medication error could occur, $66(64.7 \%)$ said during drug prescription, $81(79.4 \%)$ said during drug dispensing, while $94(92.2 \%)$ said during drug administration, and $8(7.8 \%)$ said none of the above mentioned options. Also, $78(76.5 \%)$ of the 102 respondents said 'yes' that medication error should not be reported to the patient and patient's family, while only $9(8.8 \%)$ said it should, and $15(14.7 \%)$ said they don't know.71 (69.6\%) answered 'yes' that noise making could lead to medication error, while $25(24.5 \%)$ said 'no', and $6(5.9 \%)$ said they don't know.

Table 10: Level of knowledge of medication error among the respondents

\begin{tabular}{cccccc}
\hline Knowledge & $\begin{array}{c}\text { No. of } \\
\text { respondents }\end{array}$ & $\begin{array}{c}\text { Percentage } \\
(\boldsymbol{\%})\end{array}$ & $\begin{array}{c}\text { Range } \\
\text { (scores) }\end{array}$ & Mean $(\overline{\boldsymbol{x}})$ & $\begin{array}{c}\text { Standard } \\
\text { Deviation } \\
\text { (SD) }\end{array}$ \\
\hline Adequate & 75 & 73.6 & $5-8$ & 7.69 & 1.06 \\
Inadequate & 27 & 26.4 & $0-4$ & 4.52 & 0.95 \\
\multicolumn{1}{c}{ Total } & $\mathbf{1 0 2}$ & $\mathbf{1 0 0}$ & $\mathbf{0}-\mathbf{8}$ & $\mathbf{7 . 2 1}$ & $\mathbf{2 . 0 5}$ \\
\hline
\end{tabular}

Source: Table 9

Table 10 above presents the summary of the respondents' knowledge of medication error. According to the Table, 75 (73.6\%) out of the 102 respondents had adequate knowledge of medication error with a knowledge mean score of 7.69 (1.06), while 27 (26.4\%) respondents had inadequate knowledge of medication error with a mean knowledge score of $4.52(0.95)$. In summary, a knowledge mean score of 7.21 (2.05) indicates that there is adequate knowledge of medication error among nurses in Federal Neuropsychiatric Hospital, Calabar.

\section{Research question 2: What is the attitude of nurses towards medication error in Federal Neuropsychiatric Hospital, Calabar?}

To answer this question, items $12-15$ of the questionnaire were analyzed and presented in Table 11 below. 
cognizancejournal.com

Dr. Umoh, Edet Okon et al, Cognizance Journal of Multidisciplinary Studies, Vol.1, Issue.6, June 2021, pg. 20-44

Table 11: Respondents' attitude towards medication error $(\mathrm{n}=102)$

\begin{tabular}{|c|c|c|c|c|c|c|}
\hline \multirow[t]{2}{*}{$\mathrm{S} / \mathrm{No}$} & \multirow[t]{2}{*}{ Items } & \multicolumn{5}{|l|}{ Options } \\
\hline & & SA & $\mathrm{A}$ & $\mathrm{D}$ & SD & Total \\
\hline 12. & $\begin{array}{l}\text { I would not report medication } \\
\text { error if I found that a patient is } \\
\text { given medication not prescribed } \\
\text { for him } / \text { her. }\end{array}$ & $\begin{array}{c}29 \\
(28.4 \%)\end{array}$ & $\begin{array}{c}58 \\
(56.9 \%)\end{array}$ & $\begin{array}{c}12 \\
(11.8 \%)\end{array}$ & $\begin{array}{c}3 \\
(2.9 \%)\end{array}$ & $\begin{array}{c}102 \\
(100 \%)\end{array}$ \\
\hline 13. & $\begin{array}{l}\text { It is necessary to perform proper } \\
\text { verification before } \\
\text { administering any drug to a } \\
\text { patient. }\end{array}$ & $\begin{array}{c}75 \\
(73.5 \%)\end{array}$ & $\begin{array}{c}27 \\
(26.5 \%)\end{array}$ & $\begin{array}{c}- \\
(0.0 \%)\end{array}$ & $\begin{array}{c}- \\
(0.0 \%)\end{array}$ & $\begin{array}{c}102 \\
(100 \%)\end{array}$ \\
\hline 14. & $\begin{array}{l}\text { Washing of hands before } \\
\text { preparation and administration } \\
\text { of drug is not necessary. }\end{array}$ & $\begin{array}{c}- \\
(0.0 \%)\end{array}$ & $\begin{array}{c}3 \\
(2.9 \%)\end{array}$ & $\begin{array}{c}27 \\
(26.5 \%)\end{array}$ & $\begin{array}{c}72 \\
(70.6 \%)\end{array}$ & $\begin{array}{c}102 \\
(100 \%)\end{array}$ \\
\hline 15. & $\begin{array}{l}\text { Avoiding interruptions during } \\
\text { drug rounds cannot stop } \\
\text { medication errors. }\end{array}$ & $\begin{array}{c}5 \\
(4.9 \%)\end{array}$ & $\begin{array}{c}19 \\
(18.6 \%)\end{array}$ & $\begin{array}{c}33 \\
(32.4 \%)\end{array}$ & $\begin{array}{c}45 \\
(44.1 \%)\end{array}$ & $\begin{array}{c}102 \\
(100 \%)\end{array}$ \\
\hline
\end{tabular}

Source: Questionnaire

Table 11 above presents the respondents' attitude towards medication error. The Table shows that $29(28.4 \%)$ out of the 102 respondents strongly agreed that they would not report medication error even if they found that a patient is given medication not prescribed for him/her, 58 (56.9\%) agreed, while $12(11.8 \%)$ disagreed, and 3 (2.9\%) strongly disagreed on this item. $75(73.5 \%)$ respondents strongly agreed that it is necessary to perform proper verification before administering any drug to a patient, while $27(26.5 \%)$ agreed, and none of the respondents disagreed and/or strongly disagreed respectively. Also, the Table shows that among the 102 respondents, none of the strongly agreed that washing of hands before preparation and administration of drug is necessary, $3(2.9 \%)$ agreed, while $27(26.5 \%)$ disagreed, and 72 (70.6\%) strongly disagreed. 5 (4.9\%) out of the 102 respondents strongly agreed that avoiding interruptions during drug rounds cannot stop medication errors, 19 (18.6\%) agreed on this item, while 33 (32.4\%) disagreed, and 45 (44.1\%) strongly disagreed.

Table 12: Summary of respondents' attitude towards medication error $(\mathrm{n}=102)$

\begin{tabular}{cccccc}
\hline Attitude & $\begin{array}{c}\text { No. of } \\
\text { respondents }\end{array}$ & $\begin{array}{c}\text { Percentage } \\
(\boldsymbol{\%})\end{array}$ & $\begin{array}{c}\text { Range } \\
\text { (scores) }\end{array}$ & Mean $(\overline{\boldsymbol{x}})$ & $\begin{array}{c}\text { Standard } \\
\text { Deviation } \\
\text { (SD) }\end{array}$ \\
\hline Positive & 74 & 72.5 & $9-16$ & 13.72 & 0.92 \\
Negative & 28 & 27.5 & $1-8$ & 6.69 & 1.59 \\
Total & $\mathbf{1 0 2}$ & $\mathbf{1 0 0}$ & $\mathbf{1 - 1 6}$ & $\mathbf{1 1 . 6 8}$ & $\mathbf{2 . 1 7}$ \\
\hline
\end{tabular}

Source: Table 4.9

Table 12 presents the respondents' attitude towards medication error. According to the Table, 74 (72.5\%) out of the 102 respondents had positive attitude towards medication error with an 


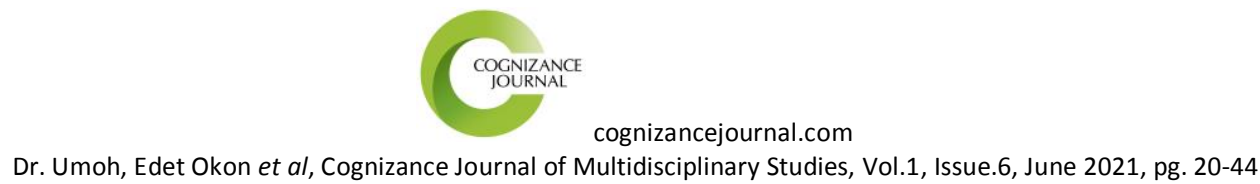

ISSN: 0976-7797

attitude mean score of 13.72 (0.92), while $28(27.5 \%)$ had negative attitude with an attitude mean score of 6.69 (1.59). The mean attitude score of 11.68 (2.17) obtained for all the respondents indicates that nurses in Federal Neuropsychiatric Hospital, Calabar has positive attitude towards medication error.

Research question 3: What are the factors affecting safe medication practices among nurses in Federal Neuropsychiatric Hospital, Calabar?

To answer this question, items 16 - 26 of the questionnaire were analysed and weighted mean scores were used for decision making. Result of this analysis is presented in Table 13 below.

Table 13: Factors affecting safe medication practices among the respondents $(\mathrm{n}=102)$

\begin{tabular}{|l|l|c|c|l|}
\hline S/No. & \multicolumn{1}{|c|}{ Factors } & $\begin{array}{c}\text { Weighted } \\
\text { mean }\end{array}$ & $\begin{array}{c}\text { Standard } \\
\text { deviation }\end{array}$ & \multicolumn{1}{|c|}{ Decision } \\
\hline 16. & Individual negligence & 3.14 & 0.31 & Significant \\
\hline 17. & Excessive workload & 3.99 & 0.57 & Significant \\
\hline 18. & Inadequate staff strength & 3.96 & 0.41 & Significant \\
\hline 19. & Poor working environment & 3.07 & 0.37 & Significant \\
\hline 20. & Lack of staff development and training. & 3.72 & 0.55 & Significant \\
\hline 21. & Poor communication system & 2.29 & 0.91 & Insignificant \\
\hline 22. & Lack of equipment and supplies & 3.58 & 0.68 & Significant \\
\hline 23. & Lack of proper supervision & 2.41 & 0.81 & Insignificant \\
\hline 24. & $\begin{array}{l}\text { Non regular review of patient's drugs } \\
\text { by doctors }\end{array}$ & 2.97 & 0.75 & Significant \\
\hline 25. & $\begin{array}{l}\text { Untimely administration of drugs by } \\
\text { nurses }\end{array}$ & 1.05 & 0.95 & Insignificant \\
\hline 26. & $\begin{array}{l}\text { Prescription of under dosage drug by } \\
\text { doctors }\end{array}$ & 2.73 & 0.79 & Significant \\
\hline
\end{tabular}

Decision Rule: $\overline{\mathbf{x}}>\mathbf{2 . 5 0}=$ Significant $\overline{\mathbf{x}} \leq \mathbf{2 . 5 0}=$ Insignificant .

The factors that affect safe medication practices among the respondents is presented in Table 13 above. According to the Table, the factors that significantly affect safe medication practice among the respondents include: individual negligence, excessive workload, inadequate staff strength, poor working environment, lack of staff development and training, lack of equipment and supplies, non-regular review of patient's drugs by doctors, and prescription of under dosage drug by doctors. The most significant factors found to affect safe medication practices among the respondents was excessive workload which is a direct consequent of inadequate staff strength in the hospital.

\section{Test of hypothesis Hypothesis One}

$\mathrm{H}_{0}$ : There is no significant relationship between knowledge and attitude of nurses towards medication error among nurses in Federal Neuropsychiatric Hospital, Calabar. 
cognizancejournal.com

Dr. Umoh, Edet Okon et al, Cognizance Journal of Multidisciplinary Studies, Vol.1, Issue.6, June 2021, pg. 20-44

$\mathrm{H}_{1}$ : There is a significant relationship between knowledge and attitude of nurses towards medication error among nurses in Federal Neuropsychiatric Hospital, Calabar

Table 14: Pearson Product Moment Coefficient of Correlation (r) computation for the relationship between knowledge and attitude of the respondents towards medication error $(n=102)$

\begin{tabular}{|ll|r|r|}
\hline & \multicolumn{1}{|c|}{ Knowledge } & Attitude \\
\hline \multirow{4}{*}{ Knowledge } & Pearson Correlation & 1 & $.951^{* *}$ \\
& Sig. (2-tailed) & & .000 \\
& $\mathrm{~N}$ & 102 & 102 \\
& Pearson Correlation & $.951^{* *}$ & 1 \\
Attitude & Sig. (2-tailed) & .000 & 102 \\
& $\mathrm{~N}$ & 102 & \\
\multicolumn{2}{|l|}{} \\
**. Correlation is significant at the 0.05 level (2-tailed).
\end{tabular}

\section{Decision}

Based on the decision rule which states that if the calculated p-value for the test statistics is less than the significant level then the null hypothesis $\left(\mathrm{H}_{0}\right)$ should be rejected; the above Table shows that the p-value (.000) associated with the computed r-value of 0.951 is less than the level of significance (0.05). With this, the null hypothesis is rejected with a conclusion that there is a significant relationship between knowledge and attitude of nurses towards medication error in Federal Neuropsychiatric Hospital, Calabar.

\section{Discussion of findings}

This study was conducted to assess knowledge and attitude of medication error among nurses in Federal Neuropsychiatric Hospital, Calabar. Findings of this study are discussed below in line with the objectives of the study.

\section{Knowledge of medication error among nurses in Federal Psychiatric Hospital, Calabar}

Results of this study revealed that majority of the study respondents have adequate knowledge of medication error. This is because these respondents knew the right meaning of medication error and therefore answered in the affirmative that medication error means giving wrong medication to a patient, and which include wrong dose, wrong route of administration, and wrong documentation. Also, majority of the study participants knew the consequence of medication error to a patient which could be inform of permanent disability or death; majority knew that medication error could result during drug prescription, drug dispensing, and during drug administration; and most of them knew that noise could lead to medication error. However, majority of the respondents did not know that it is pertinent to also report medication error to patients and even patient's family. Summarizing the respondents' knowledge of medication error the study revealed that there is adequate knowledge of medication error among nurses in Federal Neuropsychiatric Hospital, Calabar. This finding is in line with Amoula and Kambal (2015) who found a good level of knowledge of medication error among pediatric nurses in Sudan. Similarly, Simone et al (2018) also found an excellent knowledge of medication among nurses in a University Hospital in Rome. Another recent study by Ayorinde and Alabi (2019) had similar finding in Nigeria. According to these authors, the nurses used for their study have good knowledge and perception of medication error. 
cognizancejournal.com

Dr. Umoh, Edet Okon et al, Cognizance Journal of Multidisciplinary Studies, Vol.1, Issue.6, June 2021, pg. 20-44

ISSN: 0976-7797

Attitude of nurses towards medication error in Federal Neuropsychiat ric Hospital, Calabar Findings of this study revealed that majority of the nurses used for the study have positive attitude towards medication error. Accordingly, most of them would report medication error if they found a patient is given medication not prescribed for him/her; see it as a necessity to perform proper verification before administering any drug to a patient; majority strongly believe that it is necessary to wash hands before preparation and administration of drugs; and a greater proportion of the respondents strongly believe that avoiding interruptions during drug rounds cam stop medication error. On the whole, the mean attitude score obtained for all the study's participants indicates that nurses in Federal Neuropsychiatric Hospital have positive attitude toward medication error. This finding disagrees with Amoula and Kambal (2015) who reported that despite good knowledge level among their study respondents, their attitude towards medication error was negative. However, Korhan et al (2017) found positive attitude towards medication among nurses in selected Hospitals in Turkey which correlates with finding of the present study where majority of the nurses were found to have positive attitude towards medication error.

Factors affecting safe medication practices among nurses in Federal Neuropsychiatric Hospital, Calabar

Findings of this study revealed that factors that significantly affect safe medication practices among the respondents include: individual negligence, excessive workload, inadequate staff strength, poor working environment, lack of staff development and training, lack of equipment and supplies, non-regular review of patient's drugs by doctors, and prescription of under dosage drug by doctors. According to findings, the most significant factors found to affect safe medication practices among the respondents was excessive workload which is a direct consequent of inadequate staff strength in the hospital. These findings agree with Nkurunziza et al (2019) who in a literature review on factors contributing to medication error reported that inattention or negligence, lack of double checking of drugs before administration, overworked, high patient to nurse ratio, as factors that lead to medication error. Similarly, Johari et al (2016) reported heavy workload and complicated orders as factors that lead to medication among nurses in a Government Hospital in Malaysia.

\section{Relationship between variables}

Results of the test of the research hypothesis which sought to establish the relationship between knowledge and attitude of nurses towards medication error in the hospital indicates that the pvalue associated with the computed r-statistic was less than the level of significance. Hence, in line with the decision rule, the null hypothesis was rejected leading to a conclusion that there is a statistically significant and positive relationship between knowledge and attitude of nurses towards medication error in Federal Neuropsychiatric Hospital, Calabar. This shows that nurses with adequate knowledge of medication tend to show positive attitude towards medication error. 


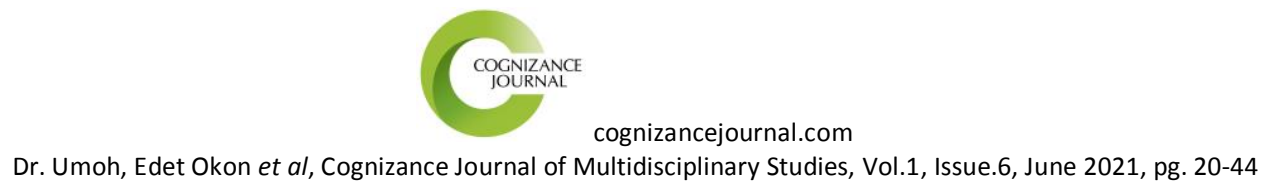

ISSN: 0976-7797

\section{Summary of findings}

The study was conducted to assess knowledge and attitude of medication error among nurses in Federal Neuropsychiatric Hospital, Calabar. Findings of this study is as summarized below:

1. Majority of the respondents were; female, aged between 31-40 years, married, Christians, were nursing officer II, and had worked in the hospital for less but not more than 10 years prior to the study.

2. There is an adequate knowledge of medication error among nurses in Federal Neuropsychiatric Hospital, Calabar. Hence, majority of the participants possess adequate knowledge of medication error.

3. Majority of the Nurses used for the study have positive attitude towards medication error indicating that there is a positive attitude towards medication error among nurses in Federal Neuropsychiatric Hospital, Calabar.

4. The factors found to significantly influence safe medication among nurses in the Hospital were; individual negligence, excessive workload, inadequate staff strength, poor working environment, lack of staff development and training, lack of equipment and supplies, non-regular review of patient's drugs by doctors, and prescription of under dosage drug by doctors.

5. There is a statistically significant relationship between knowledge and attitude of nurses towards medication error in Federal Neuropsychiatric Hospital, Calabar.

\section{Implication of the study}

Findings of this study revealed that nurses who took part in the study have adequate knowledge of medication error. Consequently, the nurses' attitude towards practice of prevention of medication error was positive. Therefore since knowledge of medication error significantly lead to a positive attitude towards its prevention, there is need to maintain the current knowledge status of these nurses. This is only possible through participation in continuous professional development such as participation in continuous education program, seminars, and workshops among others. This will enable the nurses get abreast with current development in nursing practice to aid the discharge of quality nursing services to clients such as safe medication practice.

\section{Recommendations}

Based on the results of this study, the researcher proffer the following recommendations:

1. Government should employ more qualified nurses to increase the strength of nurses in the Hospital and improve the nurse-patient ratio to avoid excessive workload which is a strong and significant contributing factor to medication error among nurses in the Hospital.

2. Management of the Hospital should organized frequent training for the nurses in form of seminars and workshops, and nurses' participation in these training programs should be made mandatory. This will enhance the nurses' knowledge and skills which are key determinant to effective and efficient professional practice. 
cognizancejournal.com

Dr. Umoh, Edet Okon et al, Cognizance Journal of Multidisciplinary Studies, Vol.1, Issue.6, June 2021, pg. 20-44

ISSN: 0976-7797

3. Strategies should be put in place to ensure that the work environment is safe, conducive and appealing to the nurses to avoid burnout and distractions while fostering safe medication practices.

4. Materials and equipment should be made available and reachable to the nurses to avoid stress while carrying out safety procedures.

\section{Suggestions for further study}

The researcher suggests that same study be carried out in other healthcare facilities within and outside Cross River State to make comparison with the results of this study.

\section{Conclusion}

Based on the findings of this study, it is concluded that nurses in Federal Neuropsychiatric Hospital, Calabar have adequate knowledge of medication error. This knowledge is wholly translated into a positive attitude towards prevention of medication error among the nurses as found in this study. However, certain factors contribute to unsafe medication practices among the nurses. Prominent among these factors include: individual negligence, excessive workload, inadequate staff strength, poor working environment, lack of staff development and training, lack of equipment and supplies, non-regular review of patient's drugs by doctors, and prescription of under dosage drug by doctors.

\section{REFERENCES}

[1]. Abbasinazari M, Zareh-Toranposhti S, Hassani A, SistanizadM, Azizian H, Panahi Y. (2016). The effectof informationprovision on reduction of errors in intravenous drugpreparation and administrationby nurses in ICUand surgical wards. Acta Med Iran; 50: 771.

[2]. Al-Youssif AS, Mohamed KL, Nabila MS. (2013). Nurses' Experiences toward Perception of Medication Administration Errors Reporting. J Nurs Heal Sci.;1:56-70.

[3]. Amoula, W.I.A. \& Kambal, I.I.A. (2015). Knowledge, attitude and practice of Nurses towards errors associated with intravenous medication administration in Paediatric Hospital - Omdurman Medical Corps Khartoum State, Sudan. International Journal of Science and Research, 6: 589-592.

[4]. Armitage G. \& Knapman H. (2018). Adverse events in drugadministration: a literature review. J Nurs Manag; 11: 130-140.

[5]. Armitage, G. (2019). Improving the quality of drug error reporting. J Eval Clin Pract;16:1189e97.

[6]. Armitage, G., \& Knapman, H. (2018). Adverse events in drug administration: A literature review. Journal of Nursing Management, 11(2), 130-140.

[7]. Aronson JK. (2009). Medication errors: What they are, how they happen, and how to avoid them. QJM;102:513-21.

[8]. Ayorinde, M.O. \& Alabi, P.I. (2019). Perception and contributing factors to medication administration errors among nurses in Nigeria. International Journal of Africa Nursing Sciences, 11: 100153.

[9]. Blignaut AJ, Coetzee SK, Kloppe $r$ HC, Ellis SM. (2017). Medicationadministration errors and relateddeviationsfrom safe practice: an observational study. J Clin Nurs; 26: 3610-3623.

[10].Bohand X, Simon L, Perrier E, Mullot H, Lefeuvre L, Plotton C. (2019). Frequency, types and potential clinical significance ofmedication-dispensing errors. CLINICS.64(1):11-6.

[11]. Buckley MS, Erstad BL, Kopp BJ, Theodorou AA, Priestley G. (2017). Direct observation approach for detecting medicationerrors and adverse drug events in a peadiatric intensive care unit. Pediatr Crit Care Med.;8(2):145-52. 
cognizancejournal.com

Dr. Umoh, Edet Okon et al, Cognizance Journal of Multidisciplinary Studies, Vol.1, Issue.6, June 2021, pg. 20-44

[12].Chiang HY, Lin SY, Hsu SC \& Ma SC(2010) Factors determining hospitalnurses' failures inreporting medicationerrors in Taiwan. Nursing Outlook58, 17-25.

[13].Di Denia P, Mingazzini A, Guglielmi V, Adamo C, Rolli M, Zanotti E, Caroli G, Baldi R. (2019). A retrospective study toevaluate the incidence of medication error occurring in the prescription andtranscription steps of the medication use process. Ig Sanita Pubbi;63:31-44.

[14].Donati D, Tartaglini D, Di Muzio M. L'errore (2015). nellasomministrazione di terapia farmacologicaendovenosanelle unità di terapia intensiva: stato dell'arte e strategie. Scenario; 32: 20-27.

[15].Ferner RE, Aronson JK. (2016). Clarification of terminology in medication errors: Definitions andclassifications. Drug Saf.;29:1011-22.

[16].Fleming S, Brady AM, Malone AM. (2018). An evaluationof the drug calculation skills of registerednurses. Nurse Educ Pract; 14: 55-61.

[17].Gastmans C. (2019). Care as a moral attitude in nursing.Nurs Ethics; 6: 214-223.

[18].Haas R, Maloney S, Pausenberger E, Keating JL, Sims J, Molloy E, et al. (2012). Clinical decision making in exercise prescription for falls prevention. PhysTher.

[19].Hsaio GY, Chen IJ, Yu S, Wei IL , Fang YY, Tang FI. (2017). Nurses' knowledge of highalertmedications: instrumentdevelopment and validation. J Adv Nurs; 66: 177-190.

[20].Hug BL, Keohane C, Seger DL, Yoon C, Bates DW. (2012). The costs of adverse drug events in community hospitals. Jt CommJ Qual Patient Saf:;38(3):120-6.

[21].Iloh, G.U.P., Chuku, A., \& Amadi, A. N. (2017). Medical Errors in Nigeria: A cross-sectional study of medical practitioners in Abia State. Archives of Medicine and Health Sciences, 5: 44-9.

[22].Johari, H., Shamsuddin, F., Idris, N. \& Hussin, A. (2017). Medication errors among Nurses in Government Hospital. IOSR-Journal of Nursing and Health Science, 1 (2): 18-23.

[23].Johnson, J. \& Thomas, M. (2016). Medication Errors: Knowledge and attitude of Nurses in Ajman, UAE. Reviews of Progress, 1 (4): 2321-3485

[24].Keers RN, Williams SD, Cooke J, Ashcroft DM. (2017). Causes of Medication Administration Errors in Hospitals: a Systematic Review of Quantitative and Qualitative Evidence. Drug Saf.;36:1045-67.

[25].Kendall-Gallagher D. \&Blegen MA . (2017). Competence andcertification of registered nurses and safetyof patientsin intensive care units. J Nurs Adm;40: S68-S77.

[26].Kim J, An K, Kim MK \& Yoon SH (2007). Nurses' perception of error reportingand patientsafety culture in Korea.Western Journal of Nursing Research29, 827-844.

[27].Kim KS, Kwon S, Kim J et al. (2011). Nurses' perceptions of medication errorsand their contributingfactors in South Korea. J Nurs Manage; 19:346- 53.

[28].Kongkaew, C, Hann M, Mandal J,Williams SD, Metcalfe D, Noyce PR, Ashcroft DM. (2013). Risk factors for hospital admissionassociated with adverse drug events. Pharmacotherapy;33:827-37.

[29].Latif A, Rawat N, Pustavoitau A, Pronovost PJ, PhamJC. (2018). National study on the distribution,causes, andconsequences of voluntarily reported medication errors between the ICU and non ICU settings. Crit Care Med; 41: 389-398.

[30].Lawton R, Carruthers S, Gardner P, Wright J,\& McEachan RR. (2016). Identifying the latent failuresunderpinning medicationadministration errors: an exploratory study.Health Serv Res; 47: 14371459.

[31].Leape LL. (1994). Error in medicine. JAMA;272:1851-68.

[32].Lisby, M.; Nielsen, L.P.; Mainz, J. (2015). Errors in the medication process: Frequency, type, and potential clinicalconsequences. Int. J. Qual. Health Care, 17, 15-22.

[33].Lu KY, Chang LC, Wu HL. (2017). Relationships betweenprofessional commitment, job satisfaction, andwork stress in public health nurses in Taiwan. J Prof Nurs; 23: 110-116.

[34].Mahmood, A., Chaudhury, H., \& Valente, M. (2011). Nurses' perceptions of how physicalenvironment affects medication errors in acute settings. Journal of Applied NursingResearch, 24,229-237.

[35].Mayo, A. M. \&Duncan, D. (2004). Nurse perceptions of medication errors: What we need toknow for patient safety; Journal of Advance Nursing; 19(3):209-17.

[36]. Mohanty, S. (2016). Awareness of medication error, medication management and prevention among staff nurses in IMS \& Sum Hospital, Odisha. Nitte University Journal of Health Sciences, 6 (4): 18-22. 
cognizancejournal.com

Dr. Umoh, Edet Okon et al, Cognizance Journal of Multidisciplinary Studies, Vol.1, Issue.6, June 2021, pg. 20-44

ISSN: 0976-7797

[37].Ndambuki, J. (2012). Factors influencing quality management ofmedication by nurses at Kenyatta National Hospital. Journal of biology,agriculture and health, 3 (18): 3-7.

[38].Nguyen, E. E., P. M. Connolly, et al. (2010). "Medication safety initiative in reducing medication errors." Journal of Nursing Care Quality, 25(3), 224-230.

[39].Nkurunziza, A., Chironda, G., Mukeshimana, M., Uwamahoro, M.C., Umwangange, M.L., \& Ngendahayo, F. (2019). Factors contributing to medication administration errors and barriers to self-reporting among nurses; A review of literature. Rwanda Journal of Medicine and Health Sciences, 2 (3): 294-303.

[40].Ogunleye, O., Oreagba, I. A., Falade, C., Isah, F., Enwere, O., Olayemi, S., Ogundele, S., Obiako, R., Odesanya, R., Bassi, P., Obodo, J., Kilani, J. \& Ekoja, M. (2016). Medication errors among health professionals in Nigeria: A national survey. International Journal of Risk \& Safety in Medicine, 28: 77-91.

[41].Petrova E, Baldacchino D \& Camilleri M(2010) Nurses' perceptions of medicationerrors inMalta. Nursing Standard24, 41-48.

[42]. Rasmussen, J. (1987). The Definition of Human Error and a Taxonomy for Technical System Design. In J. Rasmussen, K. Duncan, \& J. Leplat (Eds.), New Technology and Human Error. (pp. 23-30). Chichester: Wiley.

[43].Reason, J. (1997). Managing the risks of organizational accidents.London: Ashgate.

[44].Relihan, E., \& O'Brien, V et al. (2010). "The impact of a set of interventions to reduce interruptions and distractions to nurses during medication administration." Quality and Safety in Health Care, 19(5), e52e52.

[45]. Rothschild JM, Landrigan CP, Cronin JW, Kaushal R,Lock ley SW, Burdick E, Bate s DW. (2015). TheCritical CareSafety Study: the incidence and nature of adverseevents and serious medical errorsin intensive care. Crit Care Med; 33: 1694-1700.

[46].Sanghera, I.S.; Franklin, B.D.; Dhillon, S. (2007). The attitudes and beliefs of healthcare professionals on the causesand reporting of medication errors in a UK intensive care unit. Anaesthesia, 62,53-61.

[47]. Shahrokhi A, Ebrahimpour F, Ghodousi A. (2018). Factorseffective on medication errors: A nursing view.J Res Pharm Pract; 2: 18.

[48].Simone, E. D., Giannetta, N., Auddino, F., Cicotto, A., Grilli, D. \& Muzio M. D. (2018). Medication errors in emergency department: knowledge, attitude, behavior and training needs of Nurses. Indian Journal of critical care medicine, 22: 346-52.

[49].Tang, F., Sheu, S., Yu, S., Wei, I., Chen, C. (2007). Nurses relate thecontributing factors involvedin medical errors, volume 16, issue 3,pp.447-450.

[50].Unver, V., Tastan, S., \& Akbayrak, N. (2012). Medication errors: Perspectives of newly graduated and experienced nurses. International Journal of Nursing Practice, 18: 317-324.

[51].Wakefield, D. S., Wakefield, B. J., Uden-Holman, T., Borders, T., Blegen, M., \& Vaughn, T.(1999). Understanding why medication administration errors may not be reported.American Journal of Medical Quality, 14, 81-88.

[52].Williams, D. (2017). Medication errors. J-R Coll Physicians, 3 (4): 343

[53]. Wilmer A, Louie K, Dodek P, Wong H, Ayas N. (2019). Incidence of medication errors and adverse drug events in the ICU: Asystematic review. Qual Saf Health care 19(5):e7. 


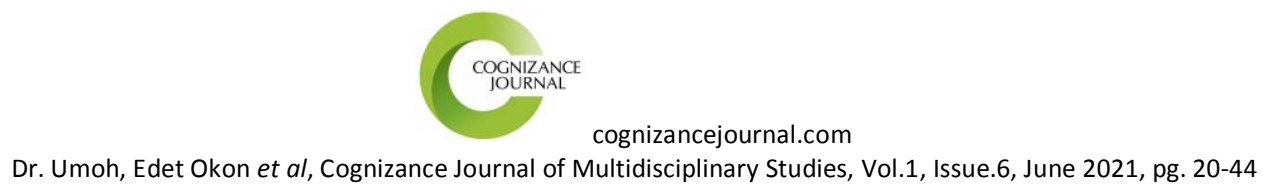

ISSN: 0976-7797

\title{
QUESTIONNAIRE
}

\section{Questionnaire on knowledge and attitude of medication error among Nurses in Federal Neuropsychiatric Hospital - Calabar}

\author{
Department of Science \& Technology \\ Nursing Science \\ National Open University
}

Dear Respondent,

I am a final year student of the above named Institution carrying out a study on the topic stated above. You are kindly requested to tick $(\sqrt{ })$ from the options that are provided. Your response will be treated with utmost confidentiality; hence your name is not required, thank you.

\section{SECTION A: SOCIO-DEMOGRAPHIC DATA}

1. Gender: Male [ ] Female [ ]

2. Age: $\leq 20 \mathrm{yrs}$ [ ] $21-30 \mathrm{yrs}$ [ ] $31-40 \mathrm{yrs}$ [ ] $41-50 \mathrm{yrs}$ [ ] Above $50 \mathrm{yrs}$ [ ]

3. Marital status: Single [ ], Married [ ], Separated [ ], Divorced [ ], Widow [ ]

4. Religion: Muslim [ ], Christianity [ ], Traditional [ ]

5. Rank: NO II [ ] NO I [ ] SNO [ ] PNO [ ] ACNO [ ] CNO [ ]

6. Years in service: $\leq 10 \mathrm{yrs}$ [ ] $11-20 \mathrm{yrs}$ [ ] $21-30 \mathrm{yrs}$ [ ] Above 30yrs [ ]

\section{SECTION B: KNOWLEDGE OF MEDICATION ERROR}

7. Medication error means giving wrong medication to the patient, which include wrong dose, wrong route, and wrong documentation.
Yes [ ]
No [ ]
I don't know [ ]

8. Medication error could cause permanent disability or death in patient
Yes [ ] No [ ] I don't know [ ]

9. Medication error could result during: (choose as many as applicable)
a. Drug Prescription
b. Drug dispensing
c. Drug administration
d. None of the above
[ ]
[ ]
[ ]

10. Medication error should not be reported to the patient and patient's family
Yes [ ]
No [ ]
I don't know [ ]

11. Noise making could lead to medication error.
Yes [ ]
No [ ]
I don't know [ ]

SECTION C: ATTITUDE TOWARDS MEDICATION ERROR

\begin{tabular}{|l|l|l|l|l|l|}
\hline S/No & Attitude of Nurses towards medication error & SA & A & D & SD \\
\hline 12. & $\begin{array}{l}\text { I would not report a medication error if I found that a } \\
\text { patient is given medication not prescribed for him/her. }\end{array}$ & & & \\
\hline 13. & $\begin{array}{l}\text { It is necessary to perform proper verification before } \\
\text { administering any drug to a patient. }\end{array}$ & & \\
\hline
\end{tabular}




\begin{tabular}{|l|l|l|l|l|l|}
\hline 14. & $\begin{array}{l}\text { Washing of hands before preparation and administration } \\
\text { of drug is not necessary }\end{array}$ & & & \\
\hline 15. & $\begin{array}{l}\text { Avoiding interruptions during drug rounds cannot stop } \\
\text { medication errors. }\end{array}$ & & & \\
\hline
\end{tabular}

SECTION D: FACTORS AFFECTING SAFE MEDICATION PRACTICES

\begin{tabular}{|l|l|l|l|l|l|}
\hline S/No & $\begin{array}{l}\text { Which of the under listed factors lead to medication } \\
\text { error in the hospital? }\end{array}$ & SA & A & D & SD \\
\hline 16. & Individual negligence & & & & \\
\hline 17. & Excessive workload & & & & \\
\hline 18. & Inadequate staff strength & & & & \\
\hline 19. & Poor working environment & & & \\
\hline 20. & Lack of staff development and training & & & & \\
\hline 21. & Poor communication system & & & & \\
\hline 22. & Lack of equipment and supplies & & & & \\
\hline 23. & Lack of proper supervision & & & & \\
\hline 24 & Non regular review of patient's drugs by doctors & & & & \\
\hline 25 & Untimely administration of drugs by nurses & & & \\
\hline 26 & Prescription of under dosage drug by doctors & & & \\
\hline
\end{tabular}

\section{APPENDIX \\ (RELIABILITY ANALYSIS)}

\begin{tabular}{|ll|r|r|}
\hline \multicolumn{2}{|c|}{ Correlations } \\
\hline \multirow{3}{*}{ Test1 } & Pearson Correlation & 1 & Retest1 \\
& Sig. (2-tailed) & & .892 \\
& $\mathrm{~N}$ & 9 & .000 \\
& Pearson Correlation & $.892^{* *}$ & 9 \\
Retest1 & Sig. (2-tailed) & .000 & \\
& $\mathrm{~N}$ & 9 & 9 \\
\hline
\end{tabular}

\begin{tabular}{|c|c|c|c|}
\hline \multicolumn{4}{|c|}{ Correlations } \\
\hline & & Test2 & Retest2 \\
\hline & Pearson Correlation & 1 & .901 \\
\hline Test2 & Sig. (2-tailed) & & .000 \\
\hline & $\begin{array}{l}\mathrm{N} \\
\text { Pearson Correlation }\end{array}$ & $.991^{9}$ & $\begin{array}{l}9 \\
1\end{array}$ \\
\hline Retest2 & Sig. (2-tailed) & .000 & \\
\hline & $\mathrm{N}$ & 9 & 9 \\
\hline
\end{tabular}




\begin{tabular}{|rl|r|r|}
\multicolumn{3}{c|}{ Correlations } \\
\hline \multirow{3}{*}{ Test2 } & \multicolumn{1}{|c|}{ Test2 } & Retest2 \\
& Pearson Correlation & 1 & .925 \\
& Sig. (2-tailed) & & .000 \\
& $\mathrm{~N}$ & 9 & 9 \\
& Pearson Correlation & .925 & 1 \\
Retest2 & Sig. (2-tailed) & .000 & \\
& $\mathrm{~N}$ & 9 & 9 \\
\hline
\end{tabular}

${ }^{* *}$. Correlation is significant at the 0.05 level (2-tailed).

\section{FEDERAL NEURO-PSYCHIATRIC HOSPITAL}

123 C ALABAR ROAD

PMB 1052 , CALABAR. CROSS RIVER STATE,

www.fnphcalabar.gov.ng
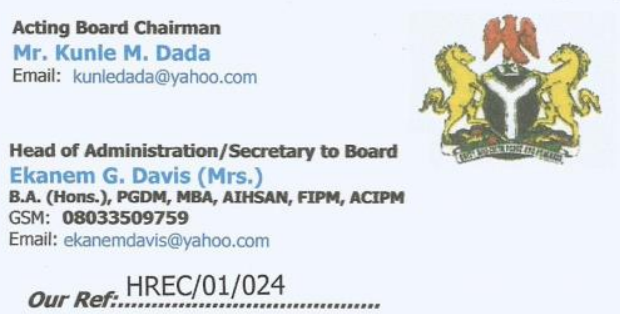

Medical Director

Dr. Bassey Edet

MBBCh, FMCPsych., FIMC, IFA

GSM: 08037192240

Email: drbasseyedet@gmail.com

Acting Head Clinical Services

Dr. Theo Osim Onyuku

MBBS (UNN) MWACPSy., FMCPsych

GSM: +2348037049507

Email: dronyuku@gmail.com

$30^{\text {Th }}$ march, 2021

Opue, Oduenyi Blessing

National Open University

Calabar Center

Calabar.

Sir/Madam,

\section{ETHICAL APPROVAL}

RE:" KNOWLEDGE AND ATTITUDE OF MEDICATION ERRORS AMONG NURSES IN FEDERAL NEURO PSYCHIATRIC HOSPITAL, CALABAR."

We wish to inform you that the Research Ethics Committee has approved your Research Proposal titled: "Knowledge and attitude of medication errors among nurses in federal neuro-psychiatric Hospital Calabar"under the supervision of Dr. Umoh, Edet Okon of the National Open University.

It is recommended that you share relevant findings of your research with the study Institution.

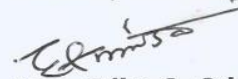

Barr. Edim O. Odey

Secretary HREC (FNPH-Cal) 